Performance Problems with Group II Hydro-Cracked Turbine Oils in Corps of Engineers Hydropower Facilities 



\title{
Performance Problems with Group 2 Hydro- Cracked Turbine Oils in Corps of Engineers Hydropower Facilities
}

\author{
John S. Micetic \\ Hydroelectric Design Center \\ Portland District \\ U.S. Army Corps of Engineers \\ P.O. Box 2946 \\ Portland, OR 97208-2946 \\ Alfred D. Beitelman \\ Engineer Research and Development Center \\ Construction Engineering Research Laboratory \\ PO Box 9005 \\ Champaign, IL 61826-9005
}

Final Report

Approved for public release; distribution is unlimited.
Prepared for U.S. Army Corps of Engineers Washington, DC 20314-1000


ABSTRACT: The Corps of Engineers has historically used solvent-refined napthenic-type base oils (Group I) for lubricating hydroelectric turbines and associated governor systems. Products now being supplied by the lubrication industry for the same purpose are based on hydro-cracked paraffinic oils (Group II). While these Group II products are advertised to have superior properties for use in gas and steam turbines, they have been reported to result in foaming and sludge formation when used in hydroelectric turbines. A survey of Corps of Engineers hydropower facilities was conducted to determine the extent of such problems. In-service evaluations were conducted to more clearly define the problem. Purpose-designed oil filtration and warming devices were installed at one Corps powerhouse to determine whether foaming and sludge formation could be prevented when using Group II oils. Initial results were positive, and four modified filtration/warming systems were subsequently installed to compare performance and refine technical specifications for a recommended system.

DISCLAIMER: The contents of this report are not to be used for advertising, publication, or promotional purposes. Citation of trade names does not constitute an official endorsement or approval of the use of such commercial products. All product names and trademarks cited are the property of their respective owners. The findings of this report are not to be construed as an official Department of the Army position unless so designated by other authorized documents.

DESTROY THIS REPORT WHEN NO LONGER NEEDED. DO NOT RETURN IT TO THE ORIGINATOR. 


\section{Contents}

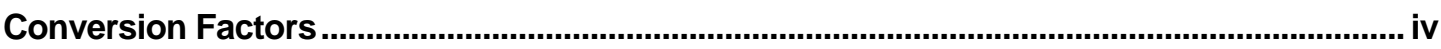

Preface.................................................................................................................. v

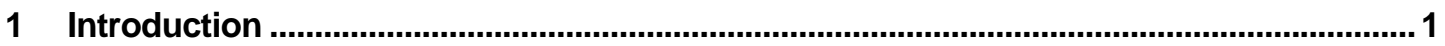

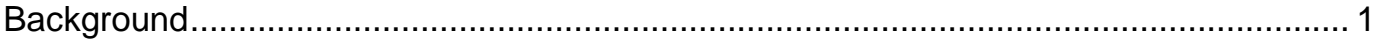

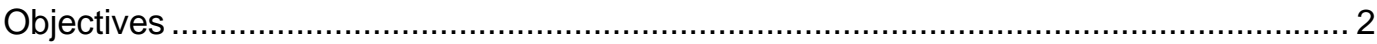

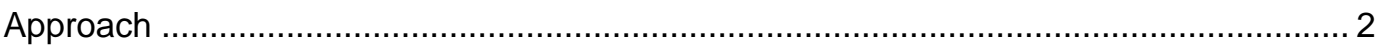

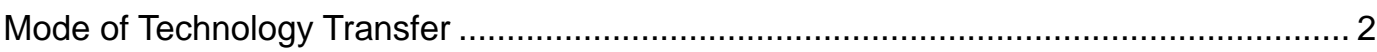

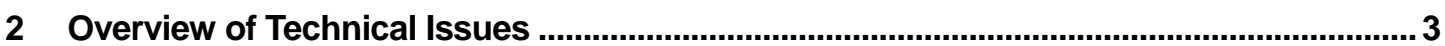

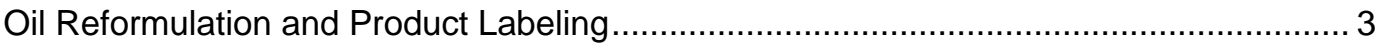

Operational Problems Encountered in Corps Powerhouses ................................... 4

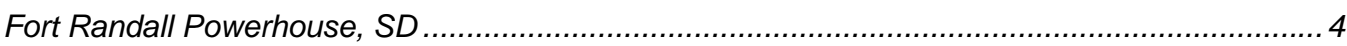

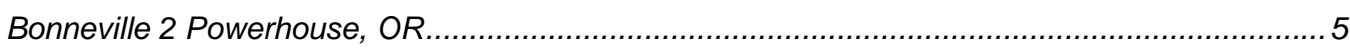

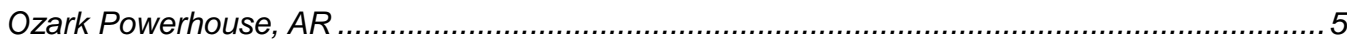

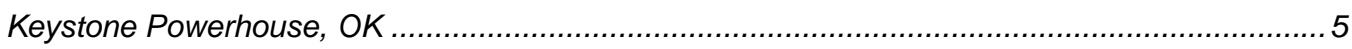

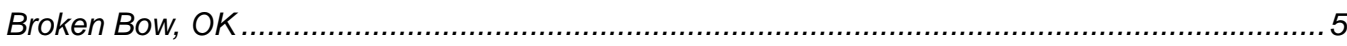

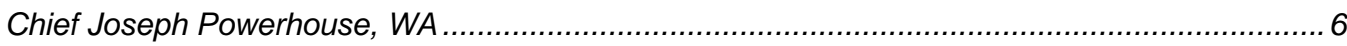

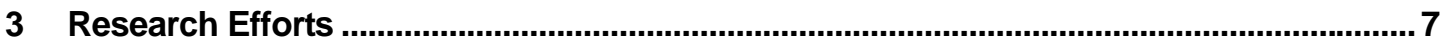

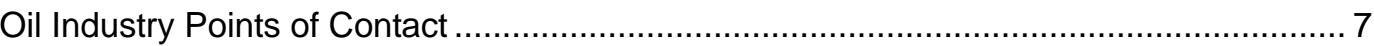

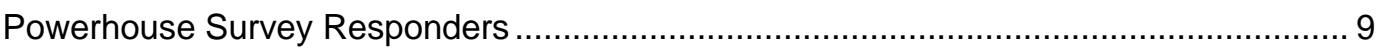

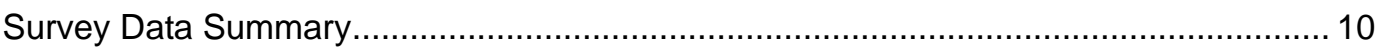

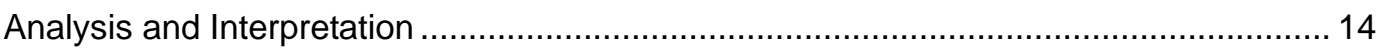

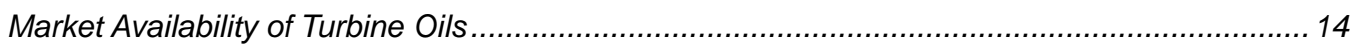

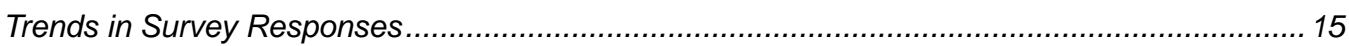

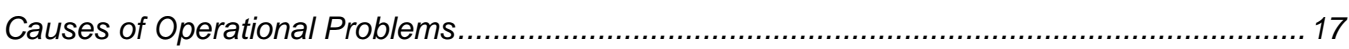

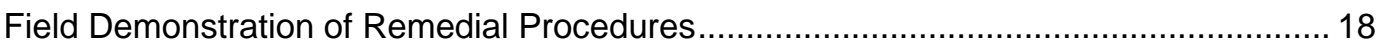

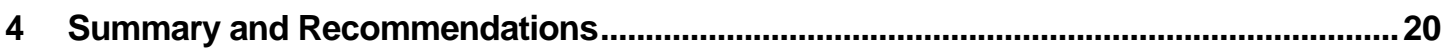

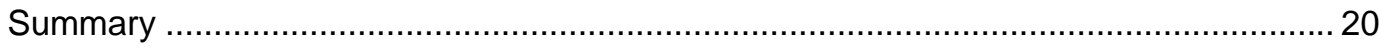

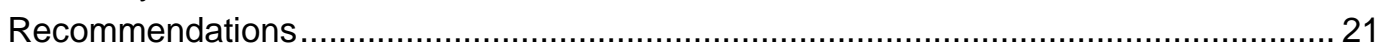

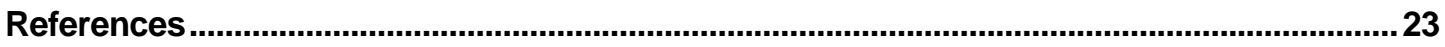

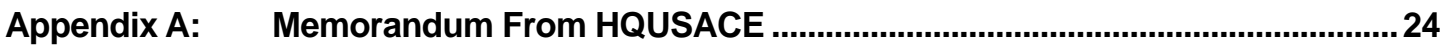

Appendix B: $\quad$ Oil Survey Questionnaire.........................................................................25 


\section{Conversion Factors}

Non-SI* units of measure used in this report can be converted to SI units as follows:

\begin{tabular}{|c|c|c|}
\hline Multiply & By & To Obtain \\
\hline acres & $4,046.873$ & square meters \\
\hline cubic feet & 0.02831685 & cubic meters \\
\hline cubic inches & 0.00001638706 & cubic meters \\
\hline degrees (angle) & 0.01745329 & radians \\
\hline degrees Fahrenheit & $(5 / 9) \times\left({ }^{\circ} \mathrm{F}-32\right)$ & degrees Celsius \\
\hline degrees Fahrenheit & $(5 / 9) \times\left({ }^{\circ} \mathrm{F}-32\right)+273.15$ & kelvins \\
\hline feet & 0.3048 & meters \\
\hline gallons (U.S. liquid) & 0.003785412 & cubic meters \\
\hline horsepower (550 ft-lb force per second) & 745.6999 & watts \\
\hline inches & 0.0254 & meters \\
\hline kips per square foot & 47.88026 & kilopascals \\
\hline kips per square inch & 6.894757 & megapascals \\
\hline miles (U.S. statute) & 1.609347 & kilometers \\
\hline pounds (force) & 4.448222 & newtons \\
\hline pounds (force) per square inch & 0.006894757 & megapascals \\
\hline pounds (mass) & 0.4535924 & kilograms \\
\hline square feet & 0.09290304 & square meters \\
\hline square miles & $2,589,998$ & square meters \\
\hline tons (force) & $8,896.443$ & newtons \\
\hline tons $(2,000$ pounds, mass $)$ & 907.1847 & kilograms \\
\hline yards & 0.9144 & meters \\
\hline
\end{tabular}

\footnotetext{
*Système International d'Unités (International System of Measurement), commonly known as the metric system.
} 


\section{Preface}

The study documented in this report was authorized by Headquarters, U.S. Army Corps of Engineers (HQUSACE) as part of Work Package 354, "Infrastructure Technologies." The work was performed under Work Unit LH8536, "Lubricants in Hydro-Turbines.” Messrs. Andy Wu and M. K. Lee, HQUSACE, were the program monitors.

The work was performed by the Materials and Structures Branch (CF-M) of the Facilities Division (CF), Construction Engineering Research Laboratory (CERL). The CERL Principal Investigator was Mr. Alfred D. Beitelman, CEERD-CF-M. The technical editor was Gordon L. Cohen, Information Technology Laboratory. Mr. Martin J. Savoie is Chief, CEERD-CF-M, and Mr. L. Michael Golish is Chief, CEERD-CF. The Technical Director for this work was Dr. Mary Ellen Hynes, CEERD-GV-T. The Director of CERL is Dr. Alan W. Moore.

CERL is an element of the U.S. Army Engineer Research and Development Center (ERDC), U.S. Army Corps of Engineers. The Commander and Executive Director of the ERDC is COL James R. Rowan and the Director is Dr. James R. Houston. 



\section{Introduction}

\section{Background}

The oil used to lubricate the guide and thrust bearings of Kaplan turbine-driven generators is generally referred to as turbine oil. The hydraulic fluid used in the generator speed governor system has many of the same requirements as the turbine lubricant, so the same oil is used for that purpose. Historically, turbine oils used in Corps hydropower facilities were formulated with solvent-refined napthenic-type base lubricants, called Group I oils. Typically the Corps and other hydroelectric plant operators buy either an ISO (International Standards Organization) 68 or $100 \mathrm{R \& O}$ (rust and oxidation inhibited) turbine oil. The numbers "68" and "100" refer to oil viscosity (68 or 100 centistokes at $100{ }^{\circ} \mathrm{F}$ ).

The current oil market is dominated by hydro-cracked paraffinic lubricants, which are known as Group II oils. These lubricants are considered the oil of choice for steam and gas turbines due to their improved purity and thermal stability. Current refining capacities and future market trending heavily favors Group II base oils, and it is projected that the production of Group I oils will be phased out. In fact, supplies of Group I turbine oil appear to be virtually impossible to find.

In addition to differences in basic formulation as compared with Group I oils, Group II turbine oils also contain new additive packages that may be incompatible with the napthenic in-service oils. Despite these changes in composition, the brand names of Group I oils have been retained for the Group II products. Without revisions in product labeling or any notification from vendors, end-users have ordered the new turbine lubricants without knowing of their changed characteristics or possible incompatibilities. To further complicate the problem, oil refiners closely guard the chemistry of their additive packages and often change them without notifying customers. It is not currently possible for end users to obtain a certification of oil compatibility for a specific application, either by an independent test laboratory or the oil refiner.

Group I oils normally last 25 years or more, but makeup oil must be added during that time to replace volume lost to leaks, evaporation, and routine mainte- 
nance activities. The addition of Group II makeup oil to Group I lubricants has resulted in problems at a number of Corps hydroelectric projects, especially excessive foaming and formation of varnish and sludge. Likewise, complete replacement of Group I oils with Group II lubricants has led to foaming and sludge formation that has plugged filters and caused erratic lubrication. One project has estimated that the cost of sludge cleanup and lost revenue due to disrupted power production was approximately $\$ 800,000$. Complete replacement of oil at a large hydroelectric project may require more than 250,000 gallons of turbine lubricant.

\section{Objectives}

The objectives of this study were to (1) identify the causes of operational problems associated with the introduction of Group II turbine oils at Corps hydroelectric projects and (2) develop and document procedures or equipment modifications necessary to use Group II turbine oils without any of the operational problems reported by Corps hydroelectric facility operators.

\section{Approach}

A survey of Corps of Engineers hydropower installations was conducted to determine the extent of the problems experienced in connection with the use of Group II turbine oils. Oil suppliers were contacted to determine the changes they made in additive selection and quantity when they changed to Group II oil. Procedures to introduce Group II oils into an existing hydropower unit were developed and field tested, and a follow-on field test was initiated to optimize the specifications of the prototype solution.

\section{Mode of Technology Transfer}

Information contained in this report will be used as a basis for developing guidance on the procurement, handling, and maintenance of oils for hydroelectric turbine systems, including requirements for filtration and oil operating temperature. Applicable findings of this study also will be incorporated in the Proponent Sponsored Engineer Corps Training (PROSPECT) course on lubrication. 


\section{Overview of Technical Issues}

\section{Oil Reformulation and Product Labeling}

Turbine oils are essential to the operation of hydroelectric power generating equipment. The basic purpose of turbine oil is to minimize friction and wear between two surfaces moving relative to one another, e.g., the guide and thrust bearings of turbine-driven generators or the moving blade mechanisms of Kaplan turbines. In addition, turbine oil dissipates heat and inhibits oxidation or corrosion, acts as a seal against outside contaminants, and flushes solid particles away from moving surfaces. Very often, this oil is also used as a hydraulic fluid in the generator's speed governor system.

The types of solvent-refined lubricating oils historically used in hydroelectric turbines are called Group I oils. Based on a survey of internet data, discussions with oil company representatives, and review of industry publications, solventrefined Group I oils are no longer readily available in the United States and Canada. Newer formulations being marketed for the same purposes, called Group II oils, are blends of base oils produced through more severe refinement methods such as hydrocracking, hydrotreating, isodewaxing or a combination of those processes. The solvency characteristic of such refined base oils is significantly lower than of the Group I oils due to a decreased presence of aromatic contents in their molecular structure. Furthermore, the new additives for these oils have chemistries different from the additives used in Group I oils and may not be fully compatible with additives already blended into the in-service oils.

The manufacturers of the new oils have not notified the Corps or other oil users of the changes being made to their products. Also, the manufacturers have not alerted users to the possibility of operational problems that could occur as a result of changes in oil characteristics or chemical incompatibilities between new additives and older ones currently in service. Because the new oils have come to market under the same trade names and designations as the older oils, users have had no way of knowing about changes in formulation or potential operating problems. 


\section{Operational Problems Encountered in Corps Powerhouses}

Since 1999, several Corps hydropower facilities have encountered serious operational problems with the new Group II oils. The problems occurred shortly after the complete replacement of the old oil or after mixing a significant amount of new oil into the in-service Group I oils while topping-off the systems. Six facilities notified the Hydroelectric Design Center (HDC) of specific problems, as discussed below.

\section{Fort Randall Powerhouse, SD}

Powerhouse personnel replaced exhausted Group I turbine oil with new Group II oil in 1999. Three months later, an increase of foaming and air entrainment in oil at governor sumps and sticking of the governor proportional valves was observed. Several months after that, the governor in-line filters started to plug with sludge, which disrupted governor operations. Foam hinders dissipation of entrained air from oil, promotes oxidation, and often causes improper ("spongy") hydraulic response of the governor. Foam also instigates lubricant starvation in the bearings, thus causing a wipeout/melting of the babbitt material. Entrained air causes cavitation in pumps. It also promotes more rapid oxidation of the oil and rampant generation of varnish particles due to adiabatic compression phenomena (micro-dieseling) in the governor system. Varnish particles, in combination with other contaminants, wear particles, and moisture, form sludge. The sludge plugs the governors' pilot in-line filters and causes operational difficulties, greater maintenance efforts, and an increase of unscheduled downtime. At Fort Randall, the problems were becoming progressively worse and a decision was made in 2000 to disassemble all eight Francis units and physically clean out accumulated sludge. This effort included removal of generators and turbine shafts in order to access thrust bearing and guide bearing sumps. The cost of this effort exceeded $\$ 800,000$. In 2001 , the system was flushed, and the cleaned units were refilled with new Group II oil and put back in service. In late 2003, plant personnel noticed a gradual increase in foaming and air entrainment of oil in governor and thrust bearing sumps. The recommended remedial actions consisted of installing a low-flow (6 - 10 gpm) off-line 3-micron absolute cellulose fiber filtration system to each governor sump. In addition, the filters needed to be equipped with low-watt density heaters capable of maintaining governor oil temperature at approximately $40{ }^{\circ} \mathrm{C}\left(105^{\circ} \mathrm{F}\right)$. Currently, due to lack of funds for acquisition of new filters, the project periodically drains oil from the sumps that have the biggest foaming problems, purifies it, and reuses it. 


\section{Bonneville 2 Powerhouse, OR}

The analysis of test data of turbine oil in 2001 showed that the oil (Group I, Mobil DTE Heavy ISO 100) was at the end of its service life, and a decision was made to replace it. The attempts made to find Group I oil on the market were unsuccessful. Compatibility testing of the proposed new oils and in-service oil, performed at the Chevron Research Laboratory by the company's own test procedure, detected three different Group II oils as being incompatible with the inservice oil. Consequently, plant personnel decided to begin the process of replacing the in-service oil with newly formulated Mobil DTE Heavy ISO 100 oil. Company representatives assured the powerhouse personnel that this oil is a blend of Group I and Group II oils, and that its characteristics are closely matched with in-service Group I oil. However, the latest Aniline Point test data showed that the most recent batch of new oil received is a Group II oil. No modifications to the equipment have been made, and the performance of the new oil is being closely monitored for signs of increased foaming and air entrainment.

\section{Ozark Powerhouse, AR}

Old Group I oil was replaced with new Group II oil in 2002. Approximately 6 months after the replacement, sludge formed in the oil and caused operational difficulties by plugging the governor in-line filters. Excessive foam and entrained air in the oil made it opaque, and a regular visual inspection of gears could not be performed without shutting down the units. The recommended remedial actions included thorough flushing of the system, adding off-line filtration systems with heaters for governor sumps, replacing old centrifuge-type purifiers with new vacuum dehydrator, and replacement of entire oil stock. No action has been taken at this time.

\section{Keystone Powerhouse, OK}

Exhausted Group I oil was replaced with Group II oil in 2003. Currently, plant personnel are observing opaqueness of the oil in governor sumps, which is caused by excessive foaming and entrained air. For this reason, the units must be stopped periodically to check the governors.

\section{Broken Bow, OK}

In early 2004, personnel mixed Group II makeup oil with in-service Group I oil. Currently, they are observing an increase of foaming and air entrainment in the oil. Remedial actions have not been taken at this time. 


\section{Chief Joseph Powerhouse, WA}

The replacement of the old Group I in-service oil with new Group II oil was completed 2001. A few months later, the same pattern of events was noticed as those described above at Fort Randall. The oil in governor sumps was developing foam and entrained air at a much higher rate than the old oil. Six months later, governor valves started to stick and sludge was plugging governor in-line filters. A year after the oil was replaced, maintenance personnel had to change filters of all units on a monthly basis in order to maintain operation.

In 2002, personnel of the Seattle District and Chief Joseph powerhouse requested assistance from the HDC to identify causes of the operational problems, and to find and recommend a solution. 


\section{Research Efforts}

HDC conducted a targeted study of the turbine oil market in terms of product types and availability. An internet search of product databases of all major oil U.S. and Canadian companies was performed. Information was collected on products by ExxonMobil, Shell, ChevronTexaco, CITGO, Hydrotex, PetroCanada, and ConocoPhillips, all of which (except Hydrotex) are current and past suppliers of oil for Corps powerhouses. In addition, many oil company representatives were contacted.

During October and November 2003 a Corps-wide survey was conducted to determine the overall field experience with turbine oils and the nature and extent of any operational problems experienced with the new turbine oils. The questionnaire and cover memo from Headquarters, USACE are attached to this report as Appendix A. The objective of the survey was to collect and catalog the following information:

- total amount, type, brand, viscosity, and age of oil used at each powerhouse

- average operational temperature of governor oils (winter/summer period)

- governor oil contamination control practices

- bulk oil stock contamination control practices

- technology base and age of oil purification equipment currently used at the powerhouses, and its performance rating

- currently established frequency of oil testing, testing methods used for evaluating serviceability of in-service oil, and tracking and trending of the tests data.

The remainder of this chapter summarizes the findings of the turbine oil market study and the user questionnaire.

\section{Oil Industry Points of Contact}

The following oil company representatives were contacted to discuss the availability of turbine oils: 


\section{ExxonMobil Oil Company}

Byron Snowden, Lubricants Application Engineer

Alan Petaja, Sales Engineer

Donovan Bresko, Vice-President of the Northwest Petroleum

John Burtsche, Senior Lubrication Specialist

Alex Mata, Mountain Pacific Sales Manager, Industrial Lubricants

Brad Jeffries, Lubricants Sales Engineer, 509-979-4206

\section{Shell Oil Company}

William Stein, Product Application Specialist

Nicky Alonso, Senior Technical Manager, Industrial Lubricants

Gene Chipman, Lubricants Sales Manager

\section{ChevronTexaco Oil Company}

Gene Jones, Lubricants Business Manager, Northwest Region

Marc Graff, Lubrication Business Manager, Northwest Business Area

Marc Okazaki, PhD., Staff Scientists, Industrial Oil Technology R\&D Lab

Boyd Stubbe, Lubricants Business Manager

Greg Anderson, Lubrication Specialist

\section{CITGO Oil Company}

Bob Green

Kline Tincher

\section{Hydrotex Oil Company}

John McConnel, Lubrication Consultant

John Cummins, Vice President, Product Technology

\section{ConocoPhillips Oil Company}

Dennis Hammons, Marketer Sales Representative

Alan Stitt, Lubrication Engineer

\section{PetroCanada Oil Company}

Dan Gabriel, US National Accounts Manager

Dr. Luc Girard, Technical Advisor

Steve Moore, Senior Technical Services Advisor 


\section{Powerhouse Survey Responders}

Survey responses were received from the following powerhouses:

\section{Fort Worth District}

Whitney Powerhouse, R.D. Willis Powerhouse, and Sam Rayburn Powerhouse

\section{Kansas City District}

Truman Powerhouse and Stockton Powerhouse

\section{Little Rock District}

Greers Ferry Powerhouse, Beaver Powerhouse, Ozark Powerhouse, Table Rock Powerhouse, and Dardanelle Powerhouse

\section{Nashville District}

Dale Hollow Powerhouse and Cheatham Powerhouse

\section{Omaha District}

Fort Peck Powerhouse, Garrison Powerhouse, Oahe Powerhouse, Fort Randall Powerhouse, Gavins Point Powerhouse, and Big Bend Powerhouse

\section{Portland District}

Bonneville First Powerhouse, Bonneville Second Powerhouse, The Dalles Powerhouse, John Day Powerhouse, Detroit Powerhouse, Big Cliff Powerhouse, Foster Powerhouse, Green Peter Powerhouse, Cougar Powerhouse, Hills Creek Powerhouse, Lookout Point Powerhouse, and Dexter Powerhouse

\section{Seattle District}

Chief Joseph Powerhouse, Albeni Falls Powerhouse, and Libby Powerhouse

\section{St. Louis district}

Clarence Cannon Powerhouse

\section{Tulsa District}

Broken Bow Powerhouse, Keystone Powerhouse, R.S. Kerr Powerhouse, Webber's Falls Powerhouse, Tenkiller Powerhouse, Denison Powerhouse, Fort Gibson Powerhouse, and Eufaula Powerhouse

\section{Vicksburg District}

Narrows Powerhouse, Blakely Powerhouse, and DeGray Powerhouse

\section{Wilmington District}

John H. Kerr Powerhouse 


\section{Survey Data Summary}

Survey responses are summarized in Table 1. Analysis of the results are provided on page 15 .

Table 1. Summary of responses to survey questionnaire.

$\begin{array}{ll}\text { Number of Districts Contacted } & 14 \\ \text { Number of Districts Responded } & 11 \\ \text { Number of Powerhouses Responded } & 46 \\ \text { Total Number of Turbine Units } & 216 \\ \text { Francis Turbines } & 111 \\ \text { Kaplan - Vertical Axis Turbines } & 79 \\ \text { Kaplan - Inclined Axis Turbines } & 14 \\ \text { Kaplan - Horizontal Axis Turbines } & 2 \\ \text { Fixed Blade Propeller Turbines } & 10\end{array}$

\section{Survey Responses}

Have you experienced an unusual increase of foaming or air entrapment after your oil has been replaced?

Describe the cause of problems, extent, and any corrective action?

Foaming \& air entrainment of governor oil

Foaming of thrust bearing oil

Foaming \& air entrainment in speed increaser oil sprayers

Have you experienced operational difficulties caused by sticking of governor valves or filter clogging after oil was replaced or makeup oil has been added?

Describe cause of problems, the extent, and any corrective action?

Valves were varnishing \& became sticky

Filters clogged

Experimenting with new filtration system

Planning to use filtration system

\begin{tabular}{c|c|c|}
$\begin{array}{c}\text { No. of } \\
\text { esponses }\end{array}$ & Yes & No \\
\hline 46 & 5 & 41 \\
\hline 2 & & \\
2 & & \\
1 & & \\
46 & 8 & 38 \\
\hline 8 & & \\
7 & & \\
1 & & \\
1 & & \\
\hline
\end{tabular}


What Group, brand and viscosity of oil is currently used in guide \& thrust bearings?

Exxon Teresstic ISO 68, estimated to be Group I (est. based on the age of oil)

Mobil DTE Heavy ISO 100, estimated to be Group I (est. based on the age of oil)

Mobil DTE Heavy ISO 100, estimated to be Group II (est. based on the age of oil)

Mobil DTE Heavy Medium ISO 68, estimated to be Group I (est. based on the age of oil)

Mobil DTE 799 ISO 68, Group II

Sunoco Sunvis ISO 68, Group I

Shell Turbo T68, estimated to be Group I (est. based on the age of oil)

Shell Turbo T68, Group II

Shell Diala, estimated to be Group I (est. based on the age of oil)

Pennzoil Pennzbell R\&O 68, Group I

CITGO Pacemaker T68, Group I

Cam ISO 68, estimated to be Group II (est. based on the age of oil)

Texaco Regal R\&O ISO 68, estimated to be Group I (est. based on the age of oil)

Texaco Regal R\&O ISO 100, Group II

Texaco Regal AW ISO 100, estimated to be Group I (est. based on the age of oil)

Chevron GST 68, estimated to be Group I (est. based on the age of oil)

Chevron AIO 68, estimated to be Group II (est. based on the age of oil)

PetroCanada ISO 68, estimated to be Group II (est. based on the age of oil)

Paceco ISO 32, estimated to be Group I (est. based on the age of oil)

ConocoPhillips ISO 100, estimated to be Group II (est. based on the age of oil)

Unknown, estimated to be Group I (est. based on the age of oil)

\section{What Group, brand and viscosity of oil is currently used in Governors?}

Exxon Teresstic ISO 68, estimated to be Group I (est. based on the age of oil)

Mobil DTE Heavy ISO 100, estimated to be Group I (est. based on the age of oil)

Mobil DTE Heavy ISO 100, estimated to be Group II (est. based on the age of oil)

Mobil DTE Heavy Medium ISO 68, estimated to be Group I (est. based on the age of oil)

Mobil DTE 799 ISO 68, Group II

Sunoco Sunvis ISO 68, Group I

Sunoco Sunula ISO 100 estimated to be Group I (est. based on the age of oil)

Shell Turbo T68, estimated to be Group I (est. based on the age of oil)

Shell Turbo T68, Group II

Shell Diala, estimated to be Group I (est. based on the age of oil)

Pennzoil Pennzbell R\&O 68, Group I

CITGO Pacemaker T68, Group I

Texaco Regal R\&O ISO 68, estimated to be Group I (est. based on the age of oil)

Texaco Regal R\&O ISO 100, Group II

Texaco Regal AW ISO 100, estimated to be Group I (est. based on the age of oil)

Chevron GST 68, estimated to be Group I (est. based on the age of oil)

Chevron AIO 68, estimated to be Group II (est. based on the age of oil)

PetroCanada ISO 68, estimated to be Group II (est. based on the age of oil)

Paceco ISO 32, estimated to be Group I (est. based on the age of oil)

ConocoPhillips ISO 100, estimated to be Group II (est. based on the age of oil)

Unknown, estimated to be Group I (est. based on the age of oil)

\begin{tabular}{|c|c|c|}
\hline $\begin{array}{l}\text { No. of } \\
\text { response }\end{array}$ & Yes & No \\
\hline 3 & & \\
\hline 3 & & \\
\hline 1 & & \\
\hline 2 & & \\
\hline 1 & & \\
\hline 1 & & \\
\hline 3 & & \\
\hline 1 & & \\
\hline 1 & & \\
\hline 1 & & \\
\hline 4 & & \\
\hline 1 & & \\
\hline 4 & & \\
\hline 1 & & \\
\hline 1 & & \\
\hline 2 & & \\
\hline 1 & & \\
\hline 1 & & \\
\hline 1 & & \\
\hline 1 & & \\
\hline 12 & & \\
\hline & & \\
\hline 3 & & \\
\hline 3 & & \\
\hline 1 & & \\
\hline 2 & & \\
\hline 1 & & \\
\hline 1 & & \\
\hline 1 & & \\
\hline 3 & & \\
\hline 1 & & \\
\hline 1 & & \\
\hline 1 & & \\
\hline 4 & & \\
\hline 4 & & \\
\hline 1 & & \\
\hline 1 & & \\
\hline 2 & & \\
\hline 1 & & \\
\hline 1 & & \\
\hline 1 & & \\
\hline 1 & & \\
\hline 12 & & \\
\hline
\end{tabular}


What Group, brand and viscosity of oil is currently used in Kaplan hubs?

Exxon Teresstic ISO 68, estimated to be Group I (est. based on the age of oil) Mobil DTE Heavy ISO 100, estimated to be Group I (est. based on the age of oil) Mobil DTE Heavy ISO 100, estimated to be Group II (est. based on the age of oil) Mobil DTE Heavy Medium ISO 68, estimated to be Group I (est. based on the age of oil) Sunoco Sunvis ISO 68, Group I

Sunoco Sunula ISO 100, estimated to be Group I (est. based on the age of oil)

Shell Turbo T68, Group II

CITGO Pacemaker T68, Group I

Texaco Regal R\&O ISO 68, estimated to be Group I (est. based on the age of oil)

Texaco Regal R\&O ISO 100, Group II

Texaco Regal AW ISO 100, Group II

Chevron GST 68, estimated to be Group I (est. based on the age of oil)

Chevron AIO 68, estimated to be Group II (est. based on the age of oil)

PetroCanada ISO 68 , estimated to be Group II (est. based on the age of oil) Unknown, estimated to be Group I (est. based on the age of oil)

What is the average age of each brand of oil?

$0-5$ yrs

5 - 10 yrs

$10-15$ yrs

15 - 20 yrs

20 - 30 yrs

$+30 \mathrm{yrs}$

Information not available

\begin{tabular}{|c|c|c} 
No. of & \\
responses & YES & NO
\end{tabular}

What is the total amount of oil in generating units at your powerhouse?

0 - 1,000 gallons

$1,000-5,000$ gallons

5,000 - 10,000 gallons

$10,000-50,000$ gallons

50,000 - 100,000 gallons

$>100,000$ gallons

What is average temperature of oil in governor sump when operating in summer?

Ambient

10 - 20 degrees $C$ (50 - 68 degrees F)

20 - 30 degrees $C$ (68 - 86 degrees F)

30 - 40 degrees $C$ (86 - 104 degrees F)

40 - 50 degrees C (104 - 122 degrees F)

Unknown / unmeasured

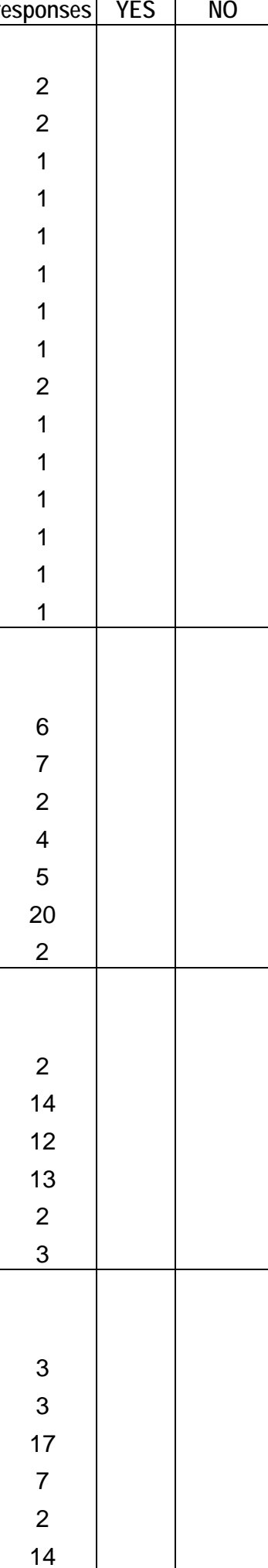


What is average temperature of oil in governor sump when operating in winter? Ambient

10 - 20 degrees $C(50$ - 68 degrees $F)$

20 - 30 degrees $C(68-86$ degrees $F)$

30 - 40 degrees $C$ (86 - 104 degrees F)

40 - 50 degrees C (104 - 122 degrees F)

Unknown / unmeasured

Is oil in the governor sump continuously filtered through a separate off-line system?

\section{Describe the system used?}

Dedicated Kidney Loop Filtration System

Occasional Use of Portable Kidney Loop Filtration System

Is the oil in the clean oil tank continuously filtered thru a separate off-line system?

What technology is used on your main oil purifier?

Centrifuge

Coalescence

Vacuum Dehydration

Filter Press System

Combination of Coalescence \& Vacuum Dehydration

\begin{tabular}{|c|c|c|}
$\begin{array}{c}\text { No. of } \\
\text { responses }\end{array}$ & Yes & No \\
\hline & & \\
3 & & \\
4 & & \\
26 & \\
2 & \\
2 & \\
9 & & \\
& & \\
46 & 4 & 42 \\
\hline
\end{tabular}

How many years has it been in service?

0 - 10 years

10 - 20 years

20 - 30 years

$>30$ years

No Information provided

\section{How would you rate its performance?}

Excellent

Very Good

Good

Adequate

Inadequate

Poor

No Information provided

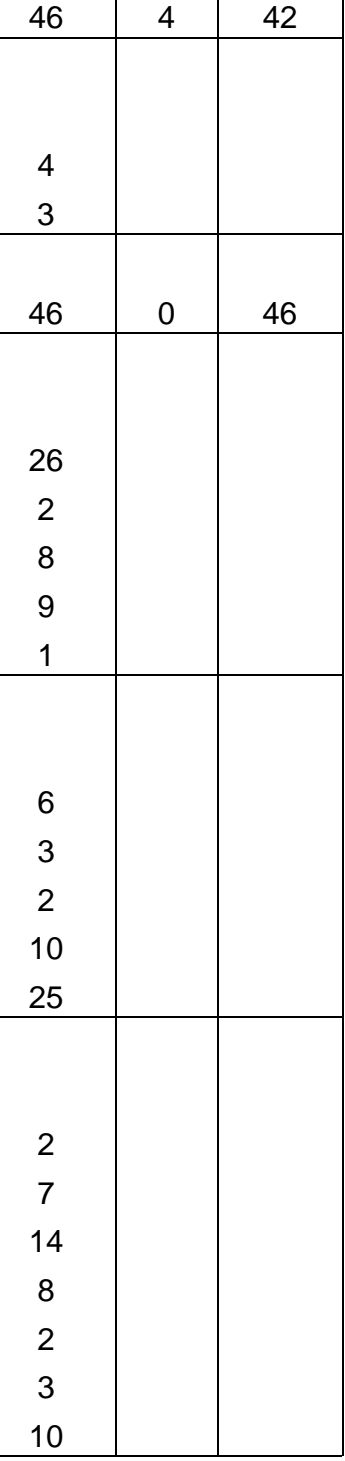


How frequently are oil samples sent to a lab for routine testing?

Bi-annually

Annually

Once in 4-5 yrs

Once in 5-10 yrs

Rarely

Never

No Information provided

Which of the oil's characteristic are checked?

Viscosity

TAN

RBOT

Metals

Moisture

Contaminants / ISO cleanliness

Depends on problem suspected

No Information provided

Describe the method used to track \& trend the continued serviceability of used oil?

Oil analysis data trends

Based on lab notification

By memory

By tracking oil temperature

None in place

No Information provided

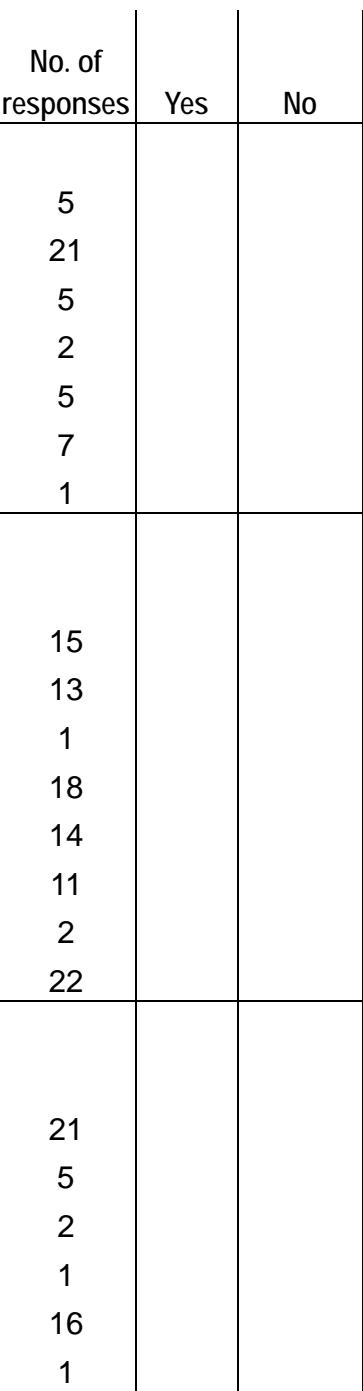

\section{Analysis and Interpretation}

\section{Market Availability of Turbine Oils}

Attempts to locate suppliers of Group I oils through internet search methods were not successful. No readily available source of turbine oil matching the characteristics of the Group I oils historically used in Corps powerhouses was identified. The salient characteristics of the oils described in all product data sheets obtained for this study indicate that the only turbine oils readily available on the market are Group II oils.

All oil company representatives contacted for this study confirmed that their turbine oils are formulated with Group II oils. They also emphasized that the new oil formulations have better thermal and oxidation stability characteristics, and 
therefore a longer service life, than the Group I oils. These advantages were attributed to the reduction in unsaturates (aromatics) and impurities (e.g., sulfur, nitrogen) achieved through refinement processes of various degrees of severity. This method of refinement makes these oils the best choice for use in steam and gas turbines, according to manufacturer representatives.

Corps powerhouse personnel, some of whom observed problems while operating with new oil, said they were not aware or alerted by oil company representatives to the changes in turbine oil formulation. In addition, personnel said they were not informed of the possibility that negative consequences may occur when the new Group II oils are mixed with the in-service Group I oils. End users reported confusion due to the marketing of the new oils under the same trade names and designation codes as the standard Group I oils.

None of the oil company representatives contacted would definitively predict whether Group I turbine oils would reappear on the market. However, most acknowledged that there is only a minute chance Group I oils would reappear because the refining capabilities for those oils is continually decreasing while growth of Group II oil production is surging North America and elsewhere in the world. This claim was verified through reference to a major industry trade publication and other sources (Tocci 2003; Sullivan 2003a; Sullivan 2003b; Kramer 2002).

Based on results of the market survey, conversations with oil company representatives, and articles by oil industry observers, it is concluded that the currently available Group II turbine oils will probably be the only type available in the future. Therefore, Corps powerhouse personnel will need to modify equipment and maintenance procedures in order to successfully use Group II oils in existing hydroelectric turbines.

\section{Trends in Survey Responses}

Survey forms were returned by personnel from 46 Corps hydroelectric powerhouses. Notable trends in the data are presented below.

1. Majority of the respondents (61\%) did not know or were not certain whether they operate with Group I or Group II oil. However, data were provided on the brands and the age of oil in service.

2. Based on information provided by oil supplier representatives, it appears that Group I oil was phased out approximately 10 years ago. Therefore, for the purpose of this report, all oils purchased within the past 10 years are as- 
sumed to be Group II oils; all oils purchased before that time are assumed to be Group I oils.

3. The 46 Corps powerhouses operate 216 turbines and collectively use approximately 902,000 gallons.

4. A majority (56\%) of responding powerhouses is operating with Group I turbine oils. No unusual operational problems were reported outside of normal maintenance requirements (e.g., changing governor in-line filters every 6 months, etc.).

5. Most of the Group I oils (57\%) have been in service more than 20 years, and $80 \%$ of those have been in service for more than 30 years. It is estimated that these oils will be replaced with Group II oils within the next 5 years.

6. Ten powerhouses (22\%) operate with a mixture of Group I and Group II oils. The majority of them (60\%) reported having operational difficulties caused by air entrainment and foaming, sticking of governor valves, and/or plugged filters.

7. It is estimated that nine Corps powerhouses (approximately 20\%) operate with Group II oils. Of those, five (approximately 55\%) are experiencing the same operational problems as powerhouses operating with mixed oils.

8. The operating temperature of governor oil in $72 \%$ of the powerhouses is below $30{ }^{\circ} \mathrm{C}\left(86^{\circ} \mathrm{F}\right)$ during the summer; in winter the total is $89 \%$. Such low temperatures can contribute to sludge formation, foaming, and air entrainment.

9. Only four powerhouses (less than 9\%) are equipped with and using kidneyloop filtration systems to continuously filter governor oil. Another three powerhouses use such filters occasionally.

10. None of the powerhouses is equipped with a dedicated filtration system for filtering bulk oil in the main storage tanks.

11. Most reporting powerhouses (80\%) use purifiers to remove moisture from oil that are based on physical phase separation (centrifuges, coalescence filters, and filter press systems). Only $20 \%$ of the powerhouses are equipped with vacuum dehydrators or a combination of coalescence-vacuum dehydrators that are based on chemical separation of water from oil.

12. It was reported that $57 \%$ of the operating purifiers have been in use for more than 20 years. Of those, $83 \%$ have been in service for more than 30 years.

13. The performance of the purifiers as rated by plant personnel, ranges from "excellent/very good" (25\%) and "good/adequate" (61\%) to "inadequate/poor" $(14 \%)$.

14. The practiced frequency of oil testing for the purpose of monitoring the quality and the serviceability of turbine oils varies from biannual testing (11\%), annual testing (46\%), once in $4-5$ years $(11 \%)$, once in $5-10$ years $(4 \%)$, or rarely (11\%). However, $16 \%$ of the reporting powerhouses have never sent oil samples to a lab for testing. 
15. When samples of oil were sent to a lab, powerhouses requested the following analyses:

- $\quad$ viscosity ( $68 \%$ of time)

- acid number (59\% of time)

- rotating pressure vessel oxidation test (4\% of time)

- elemental spectroscopy ( $82 \%$ of time)

- moisture (64\% of time)

- contaminants / ISO cleanliness ( $50 \%$ of time)

16. The majority of powerhouses (58\%) use oil analysis data to track and trend the serviceability of their turbine oil. However, a significant number of powerhouses (36\%) do not have any tracking/trending system in place.

\section{Causes of Operational Problems}

In an effort to understand why sludge forms so readily in Group II oils used in hydroelectric turbines, the characteristics of Group II oils were investigated and a forensic analysis of sludge was performed.

\section{Characteristics of Group II Oils}

Group II turbine oils are blends of severely refined base oils, also known as paraffinic-type oils, and additives. The most commonly used processes for refining Group II base oils are hydrotreating, hydrocracking, isodewaxing, and hydroisomerization, or some combination of those processes. The degree of severity of the refining process affects the characteristics and performance of the base oils. Compared with Group I oils, Group II oils have improved purity (less sulfur), and a greater percentage of saturates in its molecular structure (typically in the range of $98 \%$ or more versus approximately $80-90 \%$ for Group I oils). Decreased amounts of unsaturated content (aromatics) enhance the oil's thermal stability (i.e., resistance to thermal degradation) and decrease the rate at which its viscosity degrades when heated. This chemical structure also decreases the solvency characteristics of the oil, and its ability to keep additives well dispersed is decreased, so improved agitation is needed. This lower solvency characteristic means that Group II oils require better contamination control practices (filtration) than Group I oils. This requirement is especially important for equipment that operates at a lower temperature, such as that commonly found in the governors of hydroelectric turbines. 


\section{Sludge Analysis}

The purpose of the forensic analysis of sludge from in-service filters was to determine its composition and the chemistry of its formation. The data indicated a high load of wear and dirt particles and carboxilate salts, which form as a result of a reaction between the acidic rust inhibitor in the Group I oil and metallic cations - most often iron, zinc and copper. In addition, the analysis detected the presence of succinimide salts (reaction byproducts of rust inhibitor from the new Group II oil) and a high concentration of carbon and varnish particles (products of thermal and oxidation degradation). The rate of suspension of these polymer-like varnish particles in oil depends on the temperature and the flow rate of the oil. It is apparent that the relatively low operational temperature and flow typical of governor applications provides the conditions for agglomeration of these particles from the oil's colloidal state. The agglomerated particles encapsulated a high amount of suspended particles to form sludge, which was ultimately deposited in the governor in-line filters. The recommended remedial actions should include:

1. means to decrease the number of particles in the oil that could potentially be encapsulated

2. means to contain escalation of varnish particles, which have been identified as a component involved in the sludge buildup process

3. means to increase and maintain higher governor oil temperature

4. means to increase the mobility of oil through agitation.

\section{Field Demonstration of Remedial Procedures}

To implement the HDC recommendations at the Chief Joseph powerhouse, dedicated off-line, low-flow filtration systems equipped with 3 micron absolute cellulose fiber filters were added to two governor sumps. One of the filters was equipped with a low-watt density heater capable of maintaining oil temperature at $40{ }^{\circ} \mathrm{C}\left(105^{\circ} \mathrm{F}\right)$. After 1 month of using this system, the cleanliness of the oil in both governor sumps has been improved from ISO 20/17/13(c) to ISO 16/15/12(c). In addition, no evidence of sludge was observed on in-line filters, and foaming and air entraining rates have decreased (more so in the sump where the oil was heated). The filters operate continuously, which also greatly improves oil agitation and provides better dispersal of the additives.

The results of this demonstration proved that Group II oils can be successfully introduced into hydroelectric turbine governors with Group I oils if the additives 
of both lubricants are compatible in terms of solvency and other chemical characteristics. Although the technology solution described above is conceptually sound, it requires two refinements:

- determining the highest optimal temperature for governor oil in which the highest rate of air release can be achieved without negatively affecting the governor's hydraulic operating response

- determining the most effective technology for the filtration system, to include consideration of filter medium, pore size, dirt-holding capacity, flow rate, and flow direction, type of air release valves, controls, and safety features.

Currently at Chief Joseph powerhouse, four filtration systems with heaters rented from four different manufacturers have been installed and connected to different governor sumps. The purpose of this effort is to compare the efficiency of the different filtration technologies in the removal of varnish and other particulates typically found in the hydroelectric application. Results of the demonstration will be available for analysis in the first half of fiscal year 2005 . 


\section{Summary and Recommendations}

\section{Summary}

Group I type rust-and oxidation-inhibited (R\&O) turbine oils, which have been the standard turbine and governor lubricant used in Corps hydroelectric powerhouses, are no longer available on the market. The market for turbine lubricants is now dominated by Group II base oils and new additives, and these have led to operational problems when introduced into Corps hydropower equipment. Group II oils are expected to dominate the market for the foreseeable future, and industry experts do not foresee the reintroduction of Group I lubricants to the market.

More than half of the Corps hydroelectric powerhouses responding to a user survey reported operational problems caused by excessive foaming and air entrainment, sticking (varnishing) of the governor proportional valves, and sludge buildup plugging governor in-line filters. Analysis indicated that those problems may be attributed to a combination of the following factors:

- low solvency of Group II oils

- incompatibility between additives from new and old oils

- inadequate flushing procedures practiced during oil changeout

- low operational temperature of governor oil

- insufficient oil contamination control for the new lubricants.

The result of preliminary field tests performed at Chief Joseph powerhouse showed that hydroelectric turbines could be successfully operated with Group II oils. To be able to do so, powerhouses must modify oil contamination control procedures and increase the temperature of the governor oil. The modifications include the addition of a dedicated filtration system and a low-watt density heater to each governor sump. These measures will prevent formation and agglomeration of varnish particles in Group II oil, which occurs in poorly agitated oil at low temperature. Field-testing of different filtration systems and heaters has been conducted to identify optimal specifications for this equipment. The data collected in these tests will be analyzed in FY05, and specifications for the pre- 
ferred filtration systems and heaters will be disseminated to all Corps hydroelectric projects.

Survey data show that current governor oil contamination control practices in Corps powerhouses are not adequate or, in many cases, not established. In addition, Corps powerhouses use only a demoisturizing system to maintain adequate cleanliness of the bulk oil in storage tanks, but use no additional filtration systems. Effective filtration is essential to help ensure long equipment service life and efficient system operation.

Most Corps powerhouses still operate with Group I oil, but considering the advanced age of the oil, it appears likely that they will require replacement within 5 years. In order to maintain trouble-free operation, it is essential for those powerhouses to implement the proposed equipment modifications before replacing in-service Group I oil with Group II oil.

Oil quality and serviceability testing practices are either not adequate or are not in place at almost half of the surveyed powerhouses. Establishing such a program, to include a list of required test methods, is essential to maintaining hydroelectric turbines and governors in good operating order.

\section{Recommendations}

It is recommended that guidance for use of Group II oils be issued in FY05, and disseminated to all Corps powerhouses. The guidance should incorporate both the findings of the completed field-tests at Chief Joseph powerhouse and the best practices from the industry. This guidance should include specific information on filtration equipment requirements, procedures, and practices; specifications for governor oil heaters; and a generic description of a comprehensive flushing procedure to be completed before changeover from Group I to Group II oils. Thorough flushing is essential to eliminate potential problems caused by the incompatibility between additives from new and in-service oils or by sediments settled throughout the system. The proposed guidance also must include comprehensive information about the screening or testing of compatibility between new oils and in-service oils.

For powerhouses still operating with Group I oils and in need of a significant quantity of makeup oil, it is recommended that the entire oil stock be changed over to a Group II oil, to include the recommended upgrades of filtration equipment, oil heating devices, and flushing procedures. Until the HDC completes its 
guidance on these upgrades, however, it is recommended that powerhouses in urgent need to replace turbine oil request HDC assistance with the replacement process.

It is recommended that all oil purifiers based on physical separation of oil and water be replaced with vacuum-dehydration type demoisturizers. In addition to removing free and emulsified water, these systems also effectively remove dissolved water.

It is recommended that guidance be developed for oil testing, and for tracking and trending of test data. This guidance should include a list of required test methods, generic sampling procedures, and testing frequencies. Corps personnel should use such guidance as a tool to establish predictive maintenance and an equipment reliability program. 


\section{References}

Kramer, Dave, "Base Oil Supply / Demand and Quality Issues," presented at $8^{\text {th }}$ Annual Fuels \& Lubes Asia Conference and Exhibition, Singapore, 29 January - 1 February 2002 (F\&L Asia, Inc., 2002).

Tocci, Lisa, "Buyers Pinched as Nap Supplies Narrow," Lube Report (LNG Publishing Co., Falls Church, VA, 5 March 2003), http://www.lubereport.com.

Sullivan, Tim, "Calumet Boosting Group II Output,” Lube Report (LNG Publishing Co, Falls Church, VA, 9 September 2003a), http://www.lubereport.com.

Sullivan, Tim, "Base Oil Price Report," Lube Report (LNG Publishing Co, Falls Church, VA, 16 September 2003b), http://www.lubereport.com. 


\section{Appendix A: Memorandum From HQUSACE}

CECW-OD

17 Sep 2003

MEMORANDUM FOR RECORD

SUBJECT: Turbine Oil Questionnaire

1. We have become aware of operational problems experienced with new turbine oils. Historically, lubricating oils used in generating units at Corps hydropower facilities were formulated with solvent refined, napthenic-type base oils (Group I). Oil companies are offering Group II turbine oils, which are blended with paraffinic-type base oils. These oils have different characteristics, and consequently, are likely to exhibit substandard performance under our present operational conditions and oil contamination control practices.

2. Three Corps powerhouses, and at least one Bureau of Reclamation powerhouse recently replaced their oil with Group II oils. All are experiencing serious and almost identical patterns of operational problems, caused by excessive foaming of the oil, an increase in air entrainment, and sludge formation which causes sticking of governor proportional valves and plugging of the in-line filters. For more details see ECB 2003-17.

3. The attached questionnaire is a part of the Corps' Infrastructure Technologies Research Program, Lubricants in Hydro-Turbines. The information from this questionnaire will help HDC investigators determine the extent of problems being experienced at our facilities, and develop potential solution, determine the quantity of oil currently in use Corps-wide, modifications to equipment needed, and develop new procedures necessary to successfully convert from Group I to Group II oils.

4. This is a time sensitive request. Please provide your answers to the questions no later than Friday, November 28, 2003, and send completed Questionnaire to John Micetic of HDC (John.S.Micetic@usace.army.mil). For further information please contact John at (503) 808-4216. Your assistance is greatly appreciated.

James Crum

The Hydropower Coordinator 


\title{
Appendix B: Oil Survey Questionnaire
}

\author{
U.S. Army Corps of Engineers, Hydroelectric Design Center \\ Corps-Wide Assessment Of The Extent Of Operational Problems \\ With Oils For Generating Units In Hydroelectric Plants
}

\section{Questionnaire}

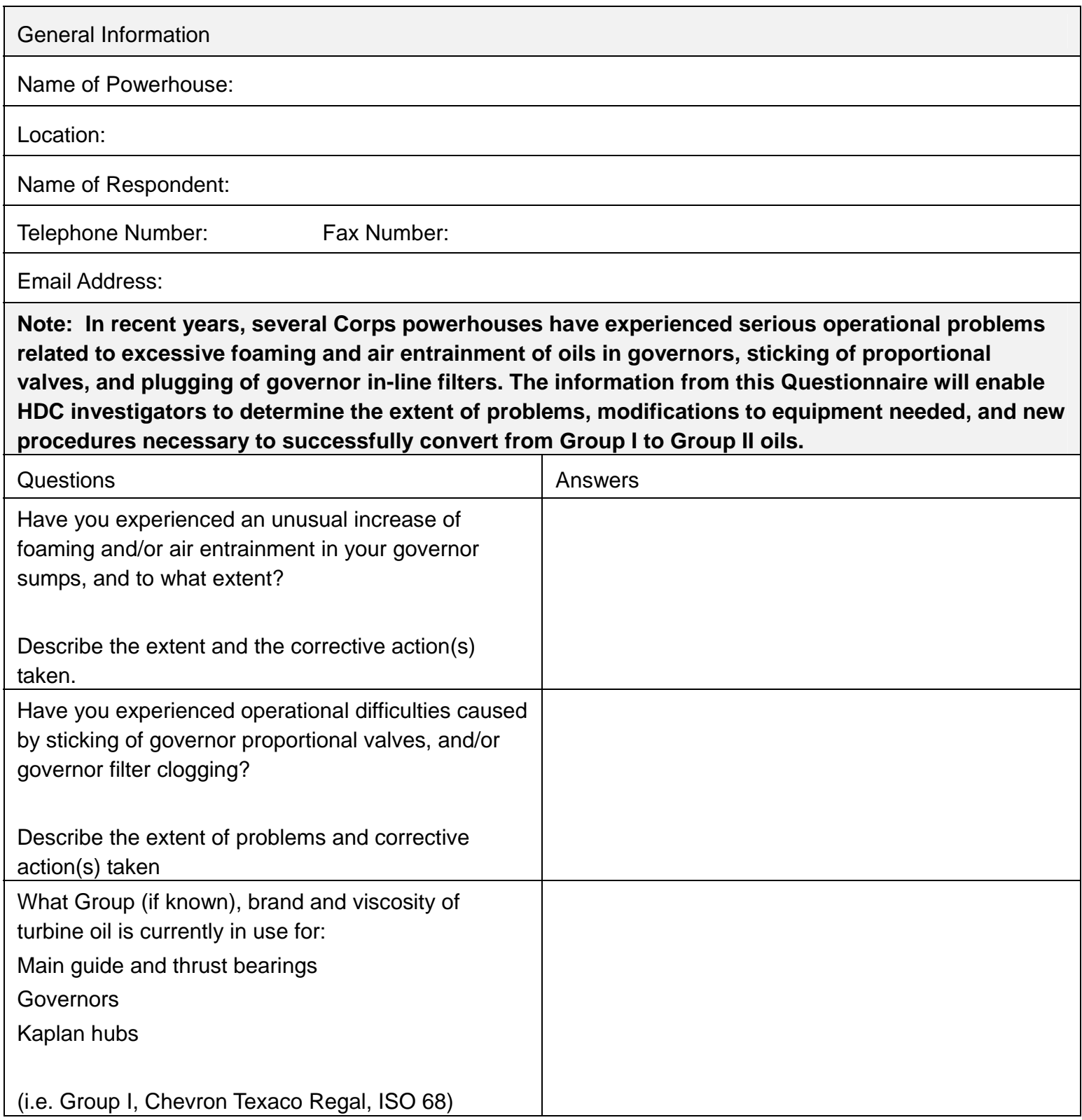




\begin{tabular}{|l|l|}
\hline What is the average age of each brand of oil? & \\
(Approx. \# of years) & \\
\hline $\begin{array}{l}\text { What is the total amount of oil in generating units at } \\
\text { your powerhouse? }\end{array}$ & \\
(Estimated gallons) &
\end{tabular}

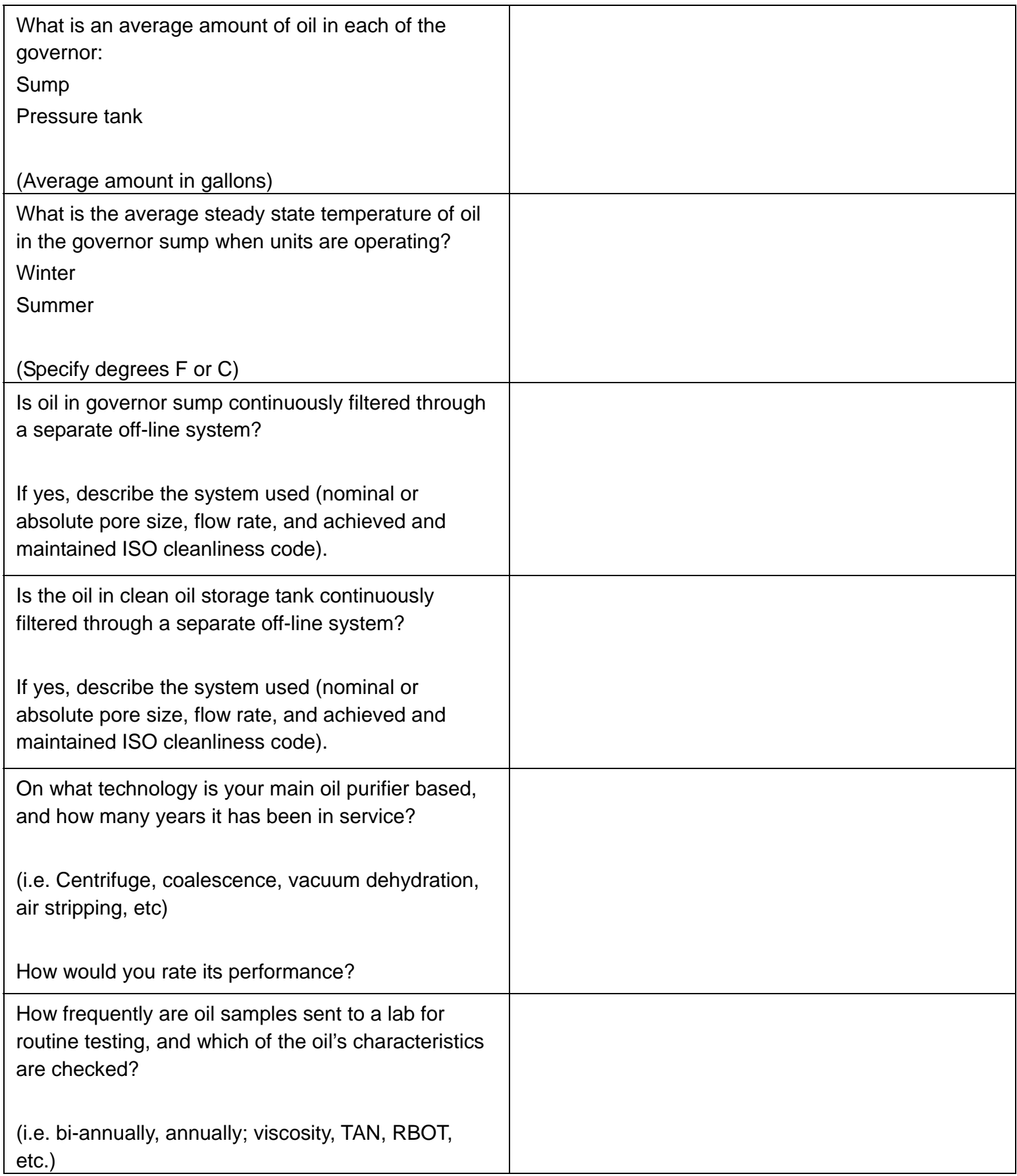


Describe the method used by the project personnel to track and trend the continued serviceability of used oil.

Additional Comments:

POC: John Micetic, Chemist Hydroelectric Design Center, HDC-T

John.S.Micetic@nwp01.usace.army.mil (503) 808-4216 
Public reporting burden for this collection of information is estimated to average 1 hour per response, including the time for reviewing instructions, searching existing data sources, gathering and maintaining the data needed, and completing and reviewing this collection of information. Send comments regarding this burden estimate or any other aspect of this collection of information, including suggestions for reducing this burden to Department of Defense, Washington Headquarters Services, Directorate for Information Operations and Reports (0704-0188), 1215 Jefferson Davis Highway, Suite 1204, Arlington, VA 22202-4302. Respondents should be aware that notwithstanding any other provision of law, no person shall be subject to any penalty for failing to comply with a collection of information if it does not display a currently valid OMB control number. PLEASE DO NOT RETURN YOUR FORM TO THE ABOVE ADDRESS.

\begin{tabular}{|c|c|c|}
\hline 1. REPORT DATE (DD-MM-YYYY) & 2. REPORT TYPE & Final \\
\hline 12-2004 & & 3. \\
\hline 4
\end{tabular}

4. TITLE AND SUBTITLE

3. DATES COVERED (From - To)

Performance Problems with Group 2 Hydro-Cracked Turbine Oils in Corps of Engineers Hydropower Facilities

5a. CONTRACT NUMBER

5b. GRANT NUMBER

5c. PROGRAM ELEMENT NUMBER

6. AUTHOR(S)

John S. Micetic and Alfred D. Beitelman

5d. PROJECT NUMBER

5e. TASK NUMBER

5f. WORK UNIT NUMBER

LH8536

8. PERFORMING ORGANIZATION REPORT NUMBER

7. PERFORMING ORGANIZATION NAME(S) AND ADDRESS(ES)
U.S. Army Engineer Research and Development Center (ERDC)

ERDC/CERL TR-04-28

PO Box 9005

Champaign, IL 61826-9005

9. SPONSORING I MONITORING AGENCY NAME(S) AND ADDRESS(ES)

HQ USACE

10. SPONSOR/MONITOR'S ACRONYM(S) HQUSACE

441 G Street, NW

Washington, DC 20314-1000

11. SPONSOR/MONITOR'S REPORT NUMBER(S)

12. DISTRIBUTION / AVAILABILITY STATEMENT

Approved for public release; distribution is unlimited.

\section{SUPPLEMENTARY NOTES}

Copies are available from the National Technical Information Service, 5285 Port Royal Road, Springfield, VA 22161.

\section{ABSTRACT}

The Corps of Engineers has historically used solvent-refined napthenic-type base oils (Group I) for lubricating hydroelectric turbines and associated governor systems. Products now being supplied by the lubrication industry for the same purpose are based on hydro-cracked paraffinic oils (Group II). While these Group II products are advertised to have superior properties for use in gas and steam turbines, they have been reported to result in foaming and sludge formation when used in hydroelectric turbines. A survey of Corps of Engineers hydropower facilities was conducted to determine the extent of such problems. In-service evaluations were conducted to more clearly define the problem. Purpose-designed oil filtration and warming devices were installed at one Corps powerhouse to determine whether foaming and sludge formation could be prevented when using Group II oils. Initial results were positive, and four modified filtration/warming systems were subsequently installed to compare performance and refine technical specifications for a recommended system.

\section{SUBJECT TERMS}

operation and maintenance

lubricants

16. SECURITY CLASSIFICATION OF: a. REPORT

Unclassified b. ABSTRACT

Unclassified generators

oils
NSN 7540-01-280-5500 c. THIS PAGE

Unclassified

\begin{tabular}{|c|c|}
$\begin{array}{l}\text { 17. LIMITATION } \\
\text { OF ABSTRACT }\end{array}$ & $\begin{array}{c}\text { 18. NUMBER } \\
\text { OF PAGES }\end{array}$ \\
SAR & 36 \\
\hline
\end{tabular}

Standard Form 298 (Rev. 8-98)

Prescribed by ANSI Std. 239.18 19a. NAME OF RESPONSIBLE PERSON Alfred D. Beitelman

19b. TELEPHONE NUMBER (include area code)

217 373-7237 